\title{
FAKTOR-FAKTOR YANG MEMPENGARUHI MINAT KONSUMEN TERHADAP JASA SERVICE HANPHONE PADA MY PONSEL
}

\section{Rika Miranda Gustiani ${ }^{1}$, Khairul Ihwan ${ }^{2}$}

Program Studi Teknik Industri, Fakultas Teknik dan Ilmu Komputer Universitas Islam Indragiri (UNISI)

Jl. Propinsi, Parit 1 Tembilahan Hulu, Tembilahan, Riau, Indonesia

Emai : Rikamirandagustian26@gmail.com, Ihwanp5@gmail.com

\begin{abstract}
ABSTRAK
Pada era saat ini komunikasi sangat berperan penting dalam kehidupan manusia seiring akan perkembangan teknologi yang sangat pesat terjadi sehingga dapat memudahkan dalam berkomunikasi yang mana pada pada zaman dulunya komunikasi jarak jauh membutuhkan waktu yang sangat susah yang di lakukan melalui surat, dengan adanya teknologi segala kegiatan di ringkas semudah mungkin seperti Handphone (Hp) yang mana dahulunya menggunakan surat dengan adanya handphone maka maka surat berubah menjadi SMS yang bisa mengirim pesan dengan seketika.Saat ini handphonebukanlah suatu hal yangdianggap mewah atau tidak langka lagi. Handphonesekarangsudah menjadi kebutuhanpokok masyarakat Indonesia. Karena mereka merasa semua bisa dilakukan dengan menggunakan Handphone tanpa kerjasama atau bantuan orang lain.Dengan meningkatnya pemakaian dan kebutuhan Ponsel di seluruh kalangan masyarakat sehingga muncul bermacam-macam masalah pada saat pemakaian sehari-hari. Ponsel adalah sebuah perangkat Elektronika yang bekerja dengan didukung oleh sebuah System yang dapat menjalankan Ponsel tersebut.Dengan adanya Rangkaian Elektronika dan System yang mengatur bekerjanya Ponsel, maka ilmu tentang perbaikan di bagi menjadi Ilmu Hardware yaitu perangkat keras dan Ilmu Software sebagai Perangkat lunaknya. Namun bagi seorang teknisi handphone haruslah memiliki kemampuan dalam mereparasi sebuah perangkat handphone secara hardware maupun software, sebab kedua elemen ini tidak dapat dipisahkan.Keadaan persaingan jasa reparasi sangat terasa sekali, persaingan ini dapat dilihat dari jumlah unit handphone yang direparasi dan masyarakat yang menggunakan jasa ini.
\end{abstract}

Kata kunci : Faktor-faktor yang mempengaruhi, minat konsumen, jasa servis handpone. 


\section{PENDAHULUAN}

MY Ponsel merupakan usaha yang bergerak dibidang jasa reparasi elektronik terutama dibidang Hanphone yang berkeduduan di jalan Gajah Mada Kecamatan Enok, Kabupaten Indragiri hilir, Riau, dalam usaha meningkatkan pelayanan usahanya MY Ponsel. Disamping mereparasi juga melayani penjualan AccesoriesHandphone seperti case, handsfre, tampredglass, dan menjual sperpakhandphonesperti LCD, Touchscreen, dll, selain itu juga menjual Pulsa Electrik maupun Voucher, Perdana, dan lain-lain. Dan Telah banyak tumbuh dan berkembang usaha

\begin{tabular}{|c|c|c|c|c|c|c|c|c|}
\hline \multirow{2}{*}{ Tahun } & \multicolumn{4}{|c|}{ Jumlah Reparasi } & \multicolumn{4}{c|}{ Pertumbuhan } \\
\cline { 2 - 9 } & Nokia & Samsung & Android & DLL & Nokia & Samsung & android & DLL \\
\hline 2014 & 500 & 350 & 420 & 340 & 0 & 0 & 0 & 0 \\
\hline 2015 & 750 & 560 & 500 & 600 & $50 \%$ & $60 \%$ & $19 \%$ & $76 \%$ \\
\hline 2016 & 900 & 780 & 800 & 650 & $20 \%$ & $39 \%$ & $60 \%$ & $8 \%$ \\
\hline 2017 & 1000 & 650 & 825 & 700 & $11 \%$ & $-16 \%$ & $3 \%$ & $8 \%$ \\
\hline 2018 & 2000 & 730 & 785 & 640 & $100 \%$ & $13 \%$ & $-4 \%$ & $-9 \%$ \\
\hline
\end{tabular}

Dari tabel di atas ternyata unit Handphone yang direparasi Pada My Ponsel, dari merk Nokia, Samsung, Android, Dll pada Tahun 2014-2018, mengalami Peningkatan jasa reparasi elektronik khususnya Handphone pada My Ponsel dikarenakan memiliki lokasi yang strategis,jaminan terhadap suku cadangyang digunakan, ongkos service yang murah serta dapat memahami permintaan masyarakat.

Aktifitas-aktifitas yang dilaksanakan tidak terlepas dari upaya peningkatan kualitas pelayanan yang diberikan. Kualitas pada umumnya dipengaruhi oleh beberapa faktor. Untuk melayani pelanggan yang dari tahun ketahun mengalami peningkatan, Dapat dilihat dari tabel di bawah ini.

Tabel 2 :Jumlah PelanganPenguna jasa diReparasi Pada My Ponsel, dari merek Nokia, Samsung, AndroidDll Tahun 2014-2018

\begin{tabular}{|c|c|c|}
\hline Tahun & Jumlah & $\begin{array}{c}\text { Persentase } \\
\text { perubahan }\end{array}$ \\
\hline 2014 & 504 & 0 \\
\hline 2015 & 671 & $33,1 \%$ \\
\hline 2016 & 709 & $5,7 \%$ \\
\hline 2017 & 1380 & $94,6 \%$ \\
\hline 2018 & 2121 & $53,7 \%$ \\
\hline
\end{tabular}

kegiatan kewirausahaan tersebut salah satunya adalah usaha yang bergerak dalam kegaitan jasa reparasi elektronik terutama Handphonedimana bentuk usaha ini dimiliki oleh perorangan yang mempunyai keahlian khusus memperbaiki Handphone dan Keadaan persaingan jasa reparasi sangat terasa sekali di Enok, persaingan ini dapat dilihat dari jumlah unit handphone yang direparasi dan masyarakat

Tabel 1 :Jumlah unit Handphone yang diReparasi Pada My Ponsel, Nokia, Samsung, AndroidDll Tahun 2014-2018 (Unit)

Dari tabel di atas dituntut adanya peningkatan pendayagunaan sumber daya manusia oleh pimpinan dalam hal perencanaan tenaga kerja, penempatan pegawai yang tepatpenyusunan dan prosedur kerja serta meningkatkan kondisi lingkungan kerja, pengawasan yang efektif dan kelancaran kerja disemua bidang untuk meningkatkan pelayanan. Apabila Aktivitas kegiatan operasional tidak dilaksanakan dan dijalankan dengan sebaik-baiknya dalam artian perusahaan tidak mampu memberikan pelayanan yang diharapkan, maka akan timbul gejala-gejala yang tidak menyenangkan bagi konsumen pemakai jasa tersebut.

Tabel 3 :Jumlah pengaduan yang diterima oleh My ponsel Tahun 2014-2018

\begin{tabular}{|c|c|c|}
\hline Tahun & Jumlah & Persentase Perubahan \\
\hline 2014 & 178 & 0 \\
\hline 2015 & 296 & $58,3 \%$ \\
\hline 2016 & 215 & $-27,4 \%$ \\
\hline 2017 & 350 & $62,8 \%$ \\
\hline 2018 & 664 & $84 \%$ \\
\hline
\end{tabular}

Dari Tabel di atas terlihat jelas bahwa tiap tahunnya terjadi peningkatan jumlah pengaduan tentang hasil reparasi handphone dari konsumen kecuali pada tahun 2017. My yang menggunakan jasa ini di Enok 
Ponsel sebagai lembaga yang melayani kepentingan orang banyak harus mampu memenuhi kebutuhan konsumennya dalam pemenuhan jasa reparasi handphone. Konsumen yang merasa tidak puas dengan pelayanan yang diberikan oleh My Ponsel mereka akan memberikan reaksi yang tidak baik salah satunya dengan melakukan komplen.

Dalam hal menangani jumlah pelanggan yang senantiasamengalami peningkatan tersebut, maka sangat dibutuhkan pegawai yang terampil dan teliti dalam menjalankan tugasnya sehingga dapat dihindarikendala-kendala yang mungkin terjadi dalam pelayanan jasa servicehandphone tersebut.

Berdasarkan data di atas dapat kita ketahui pada akhir-akhir ini My Ponsel mengalami masalah terutama pelayanan yang menurun, sedangkan jumlah pelanggan serta unit handphone daritahun-ketahun semakin meningkat. Dengan demikian ini membuat beban teknisi semakin berat.Hal ini dapat menjadi efesiensi kerja para teknisi menjadi terganggu dan akhirnya pelayanan yang diberikan kepada konsumen kurang memuaskan. Ini merupakantantangan bagi My Ponsel dalam menjalankan aktifitas perusahaan dan dalam memberikan pelayanan yang baik, Konsekwensinya mengharapkan pemenuhan/imbalan terhadap kebutuhankebutuhan yangmereka inginkan.

\section{TINJAUAN PUSTAKA}

\section{A. Sikap}

Sikap seseorang adalah Predisposisi (keadaan mudah terpengaruh) untuk memberikan tanggapan terhadap rangsangan lingkunganyang dapat memulai atau membimbing tingkah laku tersebut.

Sedangkan pengertian dari sikap itu sendiri adalah:Suatu evaluasi menyeluruh yang memungkinkan orang memberikan respon dengan cara menguntungkan secara konsisten dengan objek atau alternatif yang diberikan. (Engel, 2004:53)

Allport mendefinisikan sikap sebagai kesediaan mental yang didapatkan melalui pengalaman yang menghasilkan pengaruh kepada tindak balas individu terhadap obyek dan situasi yang berkaitan. (Mohd.Said, 2002:76)

Defenisiallport ini memerlukan beberapa penekanan dan penjelasan:

a. Defenisi ini membawa implikasi bahwa sikap adalah dipelajari

b. Sikap melibatkan situasi dan objek social.

Ciri sikap yang dapat dikesan dari defenisiallportitu ialah sikap tidak boleti dilihat secara langsung, maksudnya, sikap merupakan Suatu gagasan Hipotesa, karna itu kita hanya dapat memperhatikan sikap seseorang dengan hanya memperhatikan tingkahlakunya yang dapat dilihat, seperti ia bertindak balas terhadap rangsangan.

Di lain pihak allport juga menjelaskan arti sikap adalah : "Suatu status mental dan syaraf yang berhubungan dengan kesiapan untuk menanggapi, diorganisasi, melalui pengalaman dan memiliki pengaruh yang mengarahkan kepada prilaku"

Sementara Thurstonemendefenisikan sikap sebagai: "Suatu konsep yang cukup sederhana jumlah pengaruh yang dimiiliki seseorang atas atau suatu objek". (J.Paul Peter,2006:0)

\section{B. Perilaku Konsumen}

Perilaku konsumen adalah Perilaku yang ditunjukkan oleh orang-orang dalam hal merencanakan, membeli, dan menggunakan barang-barang ekonomi dan jasa. (Winardi, 2004:49)

Sering kali istilah Perilaku pembeli (buyerbeharvior) juga digunakan orang untuk melukiskan proses tersebut. Pada umumnya istilah perilaku pembeli memusatkan perhatian pada perilaku individu khusus yang membeli produk yang bersangkutan, sekalipun orang itu tidak terlibat dalam hal merencanakan pembelian produk tersebut. walaupun menggunakan produk tersebut.

Dalam definisi lain Perilaku konsumen adalah sebagai tindakan-tindakan dalam usaha memperoleh dan menggunakan barang-barang 
dan jasa ekonomi termasuk proses pengambilan keputusan yang mendahului dan menentukan tindakan-tindakan tersebut. (Angel, $2005: 8$ ).

\section{Harga}

Dalam arti yang sempit, harga adalah sejumlah uang yang dibayarka atas barang atau jasa. Dalam arti yang lebih luas, hargaadalah jumlah semua nilai yang konsumen tukarkan dalam rangka mendapatkan manfaat (dari) memiliki atau menggunakan barang atau jasa. Secara histories, harga telah menjadi faktor utama yang mempengaruhi pilihan pembeli.

Dalam kenyataan setiap pelanggan atau konsumen selalu memiliki kecendrungan membeli sesuatu barang adalah apabila harga yang ditawarkan layak atau tepat. Dalam menentukan harga yang tepatuntuk produk yang akan dijual, perusahaan harus mengkombinasikan sub-sub unsur harga, seperti : Tingkat harga, potongan-potongan harga dan syarat-syarat pembayaran. Untuk meningkatkan dan memperluas pasar bagi suatu produk, kebijaksanaan tentang harga ini sangat diperlukan sekali guna untuk menentukan strategi pemasaran dengan harga bisa menunjukkan keberhasilan sekaligus kegagalan perusahaan ditinjau dari jumlah pendapatan atau keuntungan yang diperoleh.

\section{METODOLOGI PENELITIAN}

\section{A. Lokasi Penelitian}

Dalam rangka penulisan ini maka penulis melakukan Penelitian pada My Ponsel diJln Gajah Mada kecamatan Enok. Penelitian ini dilakukan dari bulan Mei 2019 sampai selesai.

\section{B. Janis Dan Sumber Data}

Dalam penulisan ini penulis menggunakan dua jenis data sebagai berikut:

a. Data Primer, yaitu data yang diperoleh secara langsung dari objek penelitian seperti jawaban responden atas kuesioner yang diberikan dan data lain yang berhubungan dengan penelitian ini. b. Data Sekunder, Yakni data yang diperoleh dari dalam bentuk yang sudah jadi baik berupa laporan maupun infomasi dari pihak perusahaan ataupun pihak lain yang terkait.

\section{Metode Pengumpulan Data}

Dalam mengumpulkan data untuk keperluan penelitian, penulis menggunakan metode-metode pengumpulan data:

a. Interview, yakni mengumpulkan data melalui wawancara dengan pimpinan perusahaan dan karyawan yang terkait langsung dengan perusahaan.

b. Questioner, yaitu menyebar suatu daftar pertanyaan yang berkaitan dengan masalah yang akan dibahas dan diajukan kepada responden penelitian atau narasumber yang diharapkan dapat memberikan jawaban yang penulis butuhkan.

c. Dokumentasi, yakni data yang sudah tersedia pada My ponsel.

\section{Populasi Dan Sampel}

Populasi adalah keseluruhan dari objek atau subjek yang mempunyai kualitas dan karakteristik tertentu yang ditetapkanoleh peneliti untuk dipelajari dan kemudian ditarik kesimpulannya (Sugiyono, 2004:72). Di sini populasinya adalah para konsumen sebagai pengguna jasa servicehanphone pada My ponsel pada tahun 2019 berjumlah 2121 orang.

Sampel adalah bagian dari populasi yang akan diambil untuk mewakili populasi secara keseluruhan yang akan dijadikan responden dalam suatu penelitian. Oleh karna sangat besarnya jumlah populasi dalam penelitian ini juga keterbatasan waktu tenaga serta dana maka dalam penelitian ini penulis menggunakan metode accidental sampling yaitu pengambilan sampel berdasarkan kebutuhan, yaitu siapa saja yang secara kebetulan bertemu dengan peneliti dapat digunakan sebagai sampel. Jumlah yang akan diambil sebagai sampel dalam penelitian ini adalah 2121 orang konsumen pengguna jasa reparasi handphone pada My ponsel 
Jumlah sampel diketahui dengan mengunakan rumus Slovin(Umar, 2003:146).

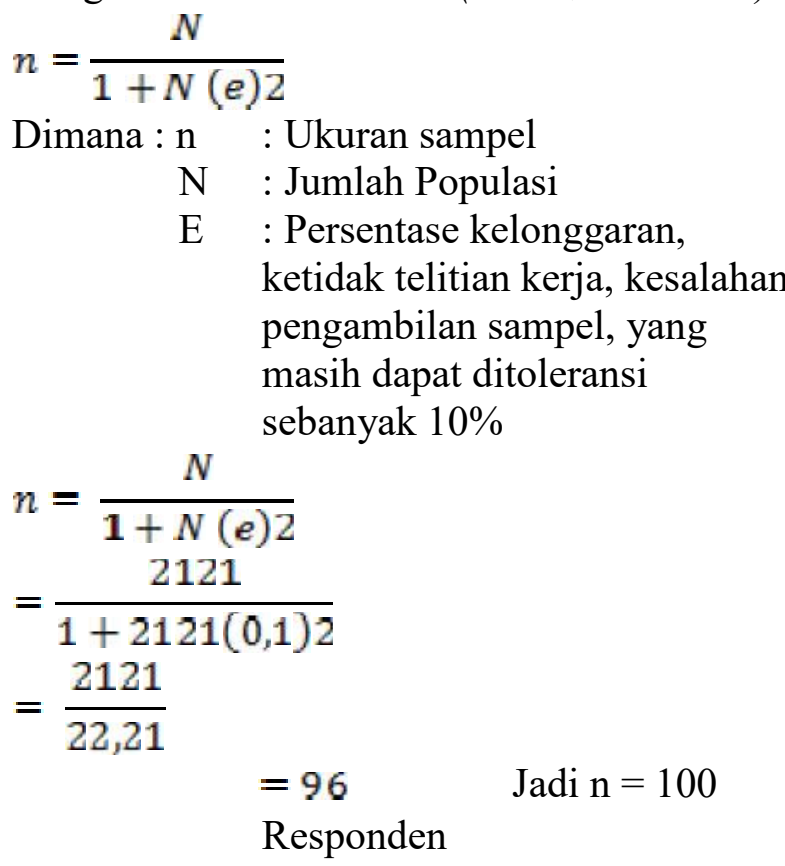

Jadi disini yang akan dijadikan sampel penelitian penulis adalah ditetapkan sebanyak 100 orang responden.

\section{E. Analisa Data}

Untuk memperoleh data yang diperoleh penulis akan mengunakan Analisa data kuantitatif dan kualitatif. Analisa kualitatif dilakukan dengan cara yakni data diperoleh darl jawaban responder berdasarkan pertanyaan yang ditabulasikan untuk dianalisa secara deskriptif kualitatif hasil data olahan berupa, table-table yang dianalisis dihubungkan dengan teori yang mendukung masalah. Sedangkan anailisis Regresi Linear Berganda yang dilakukan untuk mengukur bagaimana persepsi minat konsumen tehadap pelayanan jasa service pada My ponsel, adapun persamaan regresi berganda sebagai berikut:

$$
\begin{array}{lll}
\mathbf{Y = a}+\mathbf{b}_{1} \mathbf{x}_{\mathbf{1}}+\mathbf{b}_{\mathbf{2}} \mathbf{x}_{\mathbf{2}}+\mathbf{b}_{\mathbf{3}} \mathbf{x}_{\mathbf{3}}+\mathbf{b}_{\mathbf{4}} \mathbf{x}_{\mathbf{4}}+\mathbf{b}_{\mathbf{5}} \mathbf{x}_{\mathbf{5}}+\mathbf{e} \\
\text { Dimana: } & \mathrm{Y} & =\text { Minat konsumen } \\
\mathrm{a} & =\text { Konstanta } \\
\mathrm{b}_{1,5} & =\text { Koefisien regresi } \\
\mathrm{x}_{1} & =\text { Reliability } \\
\mathrm{x}_{2} & =\text { Tangible } \\
\mathrm{x}_{3} & =\text { Responsiveness } \\
\mathrm{x}_{4} & =\text { Assurance } \\
\mathrm{x}_{5} & =\text { Emphaty } \\
\mathrm{e} & =\text { Variabel error }
\end{array}
$$

untuk mengetahui minat konsumen terhadap jasa servicehandphohe pada My Ponsel, maka dilakukan pengujian terhadap hasil penelitian yang diantaranya Uji $\mathrm{t}$ (T-Test), dan Uji F (F-Test).

\section{F. Uji Reliabilitas Dan Validitas}

Perlu dilakukan pengujian diawal sewaktu analisa sebelum dilakukan pengujianpengujian. Hal ini bertujuan yang terkandung didalam kuesioner penelitian, perlu dilakukan pengujian diawaldisuatu analisa sebelum dilakukan pengujian-pengujian tahap, berikutnya. Hal ini bertujuan karena uji reliabilitas akan dapat menunjukkan konsistensi dari jawaban-jawaban responden terhadap pertanyaan kuisioner yang diajukan atau dapat juga dikatakan menunjukkan adanya kesamaan jawaban (yang selanjutnya menjadi data) dalam waktu yang berbeda.Dengan demikian, uji reliabilitas ini menjadi salahsatu syarat penting yang berlaku pada metode penyebaran kuisioner. Biladari uji relibilitas menunjukkan tingkat konistensi yang rendah maka kemungkinannya pernyataan yang diajukan dalam kuisioner tidak dapat ditangkapdengan baik oleh responden, sehingga bila diajukan dalam waktu yang berbeda, jawabannya, pun akan berbeda. Dasar pengambilan keputusan uji reliabilitas adalahjikaalpha $>\mathrm{r}$ tabel maka butiran atau variabel tersebut reliable. Sedangkan Uji Validitas Uji validitas dilakukan untuk mengetahui apakah alat ukur yang telah disusun dapat digunakan untuk mengukur apa yang hendak diukur secara, tepat. Validitas suatu instrument akan menggambarkan tingkat kemampuan alat ukur yan digunakan untuk mengungkapkan sesuatu yang menjadi sasaran pokok pengukuran. Dengan demikian, permasalahan validitasinstrument (kuisioner) akan menunjukkan pada mampu tidaknya instrument (kuisioner) akan menunjukkan yang diukur. Jika $r$ hasil $>$ tabel dapat disimpulkan bahwa instrument yang digunakan valid sebaliknya jika $r$ hasil $<r$ tabel maka dapat disimpulkan bahwa instrument yang digunakan tidak valid. 


\section{G. Hipotesis}

Berdasarkan latar belakang masalah dan uraian yang telah penulis kemukakan sebelumnya, maka penulis merumuskan hipotesis : "diduga Faktor-faktor yang mempengaruhi minat konsumen tehadap jasa servicehanphone pada My ponsel meliputi faktor Reliability, Tangible, Responsiveness, Assurance, Emphaty".

\section{H. Variabel Penelitian}

Variabel-Variabel yang akan di teliti antara lain

1. Variabel Terikat (Y) adalah : Minat Konsumen

2. Variabel Bebas $(\mathrm{X})$ adalah :
a. Reliability/Keandalan (X1)
b. Tangible/Bukti fisik (X2)
c. Responsiveness/Ketanggapan (X3)
d. Assurance/Keyakinan (X4)
e. Empaty/Perhatian yang tulus (X5).

\section{HASIL DAN PEMBAHASAN \\ A. Identivikasi Umum Responden}

Penelitian dilaksanakan pada tahun 2010, dengan menyebarkan seratus lembar isian kuisioner pada pelanggan pemakai jasa Service handphone pada My ponsel. Dari jumlah tersebut Seluruhnva mengisi secara lengkap dan diperoleh data gambar tabel 4. 1 sebagai berikut:

Tabel4 : Identitas Umum Responden

\begin{tabular}{|l|c|c|}
\hline \multicolumn{1}{|c|}{ Indikator } & jumlah & Persentase \\
\hline Jenis kelamin & & \\
-Laki-Laki & 76 & $76 \%$ \\
-Perempuan & 24 & $24 \%$ \\
\hline Pekerjaan & & \\
-PNS & 27 & $27 \%$ \\
-Swasta & 61 & $61 \%$ \\
-Rumah Tangga & 12 & $12 \%$ \\
\hline
\end{tabular}

\section{B. Deskripsi Variabel Minat Konsumen}

Dalam pemasaran jasa service merupakan masalah utama yang harus ditangani karena menyangkut kepuasan konsumen dan pelanggan. Kepuasan dapat dilihat dari baik atau buruknya kualitas pelayanan yang diberikan sehingga dapat menimbulkan kesan puas terhadap barang atau jasa yang dipilih. Sedangkan pelayanan yang tidak baik pada dasarnya cenderung akan membuat calon konsumen dan pelanggan mengurungkan niatnya untuk membeli barang atau jasa yang ditawarkan perusahaan tersebut, karna konsumen dan pelanggan tidak hanya membutuhkan pemenuhan kebutuhannya saja melainkan pelayanan yang baik dan Memuaskan.

Bagi pelangan itu sendiri, pelayanan merupakan satuhal yang wajar, jika rasanya dan tuntutan terhadap kebutuhan dan harga diri mereka sebagai "raja" dapat selalu terpenuhi, selalu mendapatkan penawaraan produk dan jasa yang baik, dan ingin adanya tanggung jawab mutu pelayanan yang diberikan perusahaan tersebut.

\section{Analisa Minat Konsumen Terhadap Jasa Servis Handphone}

Pelanggan akan merasa puas apabila perusahaan memberikan layanan dengan kualitas jasa servicehanphone yang baik, dan diikuti dengan tarif yang murah, pengaduan yang cepat dilayani serta hasil yang sangat memuaskan. Hal ini dibuktikan secara kualitatif rata-rata sebagian besar responden mementingkan kualitas jasa service yang baik dari Be-en Ponsel Pekanbaru. Untuk mengetahui minat konsumen terhadap perusahaan dapat kita lihatpada tabel di bawah ini :

Tabel 5 :Tanggapan Responden Terhadap Kesadaran yang tinggi dari teknisi Service Handphone dalam melayani

\begin{tabular}{|c|c|c|c|}
\hline $\begin{array}{l}\mathrm{N} \\
\mathrm{o}\end{array}$ & Alternatif Jawaban & $\begin{array}{l}\text { Jumlah } \\
\text { responde } \\
n\end{array}$ & $\begin{array}{c}\text { Persentas } \\
\text { e }(\%)\end{array}$ \\
\hline $\begin{array}{l}1 \\
2 \\
3\end{array}$ & $\begin{array}{ll}\text { a. } & \text { Memuaskan } \\
\text { b. } & \text { Cukup } \\
& \text { Memuaskan } \\
\text { c. Kurang } & \text { Memuaskan }\end{array}$ & $\begin{array}{c}75 \\
20 \\
5\end{array}$ & $\begin{array}{c}75 \% \\
20 \% \\
5 \%\end{array}$ \\
\hline & Total Responden & $\begin{array}{c}100 \\
\text { responde } \\
n\end{array}$ & $100 \%$ \\
\hline
\end{tabular}

Sumber: Data Olahan 
Berdasarkan tabel 5 dapat diketahui tanggapan responden Terhadap Kesadaran yang tinggi dari teknisi Service Handphonedalam melayani, yang menjawab memuaskan 75 orang responden, yang menjawab cukup memuaskan 20 orang responden dan yang menjawab kurang memuaskan sebanyak 5 orang responden.

Tabel 6 : Tanggapan Responden Terhadap Kapasitas Mesin Service Hanphone

\begin{tabular}{|c|c|c|c|}
\hline $\begin{array}{l}\mathrm{N} \\
\mathrm{o}\end{array}$ & Alternatif Jawaban & $\begin{array}{c}\text { Jumlah } \\
\text { responde } \\
n\end{array}$ & $\begin{array}{c}\text { Persentas } \\
\text { e (\%) }\end{array}$ \\
\hline $\begin{array}{l}1 \\
2 \\
3\end{array}$ & $\begin{array}{ll}\text { a. } & \text { Lengkap } \\
\text { b. } & \text { Cukup } \\
& \text { Lengkap } \\
\text { c. } & \text { Kurang } \\
& \text { Lengkap }\end{array}$ & $\begin{array}{c}7 \\
77 \\
16\end{array}$ & $\begin{array}{c}7 \% \\
77 \% \\
16 \%\end{array}$ \\
\hline & Total Responden & $\begin{array}{c}100 \\
\text { responde } \\
n\end{array}$ & $100 \%$ \\
\hline
\end{tabular}

Berdasarkan tabel 6 dapat diketahui tanggapan responden Terhadap sikap teknisi dalam menindak lanjuti segala keluhanpelanggan, yang menjawab cepat tanggap 7 orang responden, yang menjawab cukup tanggap 77 orang responden dan yang menjawab kurang tanggap sebanyak16 orang responden.

\section{Faktor-Faktor Yang Mempengaruhi Minat Konsumen Terhadap Jasa ServisHandphone}

Analisis data ini dapat digunakan untuk pengujian hipotesis pada variabel-variabel yang telah disusun sebelumnya dari variabel Reliability $\left(\mathrm{X}_{1}\right)$, veriabletangible $\left(\mathrm{X}_{2}\right)$, variabel responsiveness $\left(X_{3}\right)$, variableassurance $\left(X_{4}\right)$, dan variableempaty $\left(\mathrm{X}_{5}\right)$ yang diduga berpengaruh dan mempunyai hubungan terhadap minat konsumen (Y).
Tabel 7 :Analisis Regresi

\begin{tabular}{|l|l|l|l|l|}
\hline Model & $\begin{array}{l}\text { Koefisien } \\
\text { regresi }\end{array}$ & $\begin{array}{l}\text { T- } \\
\text { Hitung }\end{array}$ & $\begin{array}{l}\text { T- } \\
\text { tabel }\end{array}$ & Signifikan \\
\hline Constantant & 2,242 & - & - & 0,111 \\
\hline Variable $\mathrm{x}_{1}$ & 0,242 & 3,544 & 1,980 & 0,001 \\
\hline Variable $\mathrm{x}_{2}$ & 0,288 & 3,419 & 1,980 & 0,001 \\
\hline Variable $\mathrm{x}_{3}$ & 0,153 & 2,217 & 1,980 & 0,026 \\
\hline Variable $\mathrm{x}_{4}$ & 0,181 & 2,160 & 1,980 & 0,033 \\
\hline Variable $\mathrm{x}_{5}$ & 0,170 & 2,102 & 1,980 & 0,038 \\
\hline
\end{tabular}

Table7 merupakan kumpulan hasil jawaban dari responden berdasarkan variablevariable minat konsumen terhadap jasa servicehanphone pada My ponsel. Dari tabel diatas dapat kita lihat bahwa variablereliability $\left(\mathrm{X}_{1}\right), \quad$ tangible $\left(\mathrm{X}_{2}\right)$, responsiveness $\left(\mathrm{X}_{3}\right), \quad$ assurance $\left(\mathrm{X}_{4}\right)$, empaty $\left(X_{5}\right)$ sangat diterima sebagai faktor yang mempengaruhi minat konsumen terhadap jasa servicehanphone pada My ponsel, Variablevariable tersebut saling terikat dengan variable bebasnya (Y).

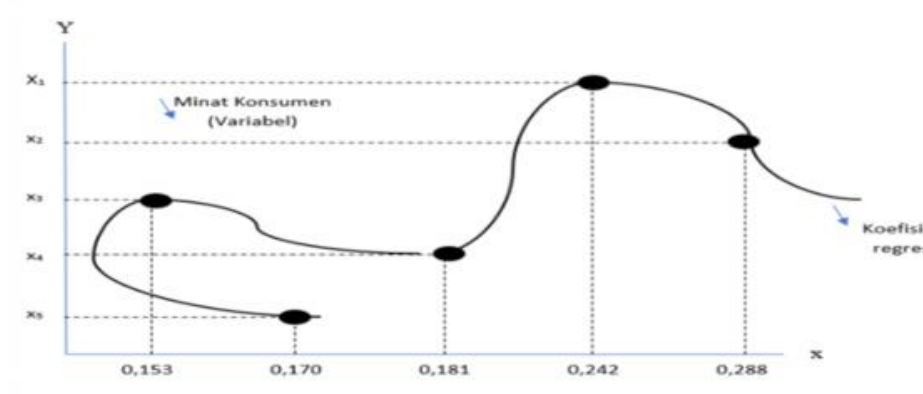

Berdasarkan Grafikdiatas maka dapat kita ketahui sebagai persamaan regresi linear berganda dalam analisi ini adalah sebagia berikut :

$Y=2,242+0,242 X_{1}+0,288 X_{2}+0,153 X_{3}+$ $0,181 \mathrm{X}_{4}+0,170 \mathrm{X}_{5}+\mathrm{e}$

Dari table 20 dan persamaan regresi dengan tingkatkepercayaan $(\alpha) \quad 5 \%$ sebesar $\quad 1,980$ sebagai berikut :

1. Uji Terhadap pengaruh Variablereliability $\left(\mathrm{X}_{1}\right)$ terhadap variable minat konsumen ( $\mathrm{Y}$ ) menunjukan nilai t- hitung sebesar 3,544 atau lebih besar dari pada t- 
table ( 1,980). Hal ini menunjukan bahwa variablereliability $\left(\mathrm{X}_{1}\right)$ mempunyai pengaruh positif terhadap variable minat konsumen (Y) artinya bahwa minat konsumen akan berubah sebesar O,242 Jika dengan asumsi variable lainnya dianggap konstan (tetap).

2. Uji terhadap pengaruh variabletangible $\left(\mathrm{X}_{2}\right)$ terhadap variable minat konsumen (Y) menunjukan nilai thitung sebesar 3,419 atau lebih besar dari pada t- table ( 1,980$)$. Hal ini menunjukan bahwa variabletangible $\left(\mathrm{X}_{2}\right)$ mempunyai pengaruh positif terhadap variable minat konsumen (Y), artinya minat konsumen akan berubah sebesar 0,288 jika dengan asumsi variable lainnya dianggap konstan (tetap).

3. Uji terhadap pengaruh variableResponsiveness $\left(\mathrm{X}_{3}\right)$ terhadap variable minat konsumen (Y) menunjukan nilai t- hitung sebesar 2,217 atau lebih besar dari pada t- table ( 1,980$)$. Hal ini menunjukan bahwa variableResponsiveness $\left(\mathrm{X}_{3}\right)$ mempunyai pengaruh positif terhadap variable minat konsumen (Y), artinya minat konsumen akan berubah sebesar 0,153 jika dengan asumsi variable lainnya dianggap konstan (tetap).

4. Uji terhadap pengaruh variableassurance $\left(\mathrm{X}_{4}\right)$ terhadap variable minat konsumen $(\mathrm{Y})$ menunjukan nilai t- hitung sebesar 2,160 atau lebih besar daripada ttable ( 1,980). Hal ini menunjukan bahwa variableassurance $\left(\mathrm{X}_{4}\right)$ mempunyai pengaruh positif terhadap variable minat konsumen (Y), artinya sikap akan berubah sebesar 0,181 jika dengan asumsi variable lainnya sianggap konstan (tetap).
5. Uji terhadap pengaruh variableempaty $\left(\mathrm{X}_{5}\right)$ terhadap variable minat konsumen $(\mathrm{Y})$ menunjukan nilai thitung sebesar 2,102 atau lebih besar dari pada t- table ( 1,980$)$. Hal ini menunjukan bahwa variableempaty $\left(\mathrm{X}_{5}\right)$ mempunyai pengaruh positif terhadap variable minat konsumen (Y), artinya sikap akan berubah sebesar 0,170 jika dengan asumsi variable lainnya sianggap konstan (tetap).

Berdasarkan kelima analisis diatas dapat diketahubahwaivariablereliability $\left(\mathrm{X}_{1}\right)$, tangible $\left(\mathrm{X}_{2}\right)$,responsiveness $\left(\mathrm{X}_{3}\right)$,

assurance $\left(\mathrm{X}_{4}\right)$, empaty $\left(\mathrm{X}_{5}\right)$, mempunyai pengaruh yang besar terhadap variable minat konsumen (Y). Hal ini dapat ditunjukan bahwa t- hitung semua variable lebih besar dari pada ttabel.

Hal ini membuktiakan bahwa variablereliability $\left(\mathrm{X}_{1}\right)$, tangible $\left(\mathrm{X}_{2}\right)$, Responsiveness $\left(\mathrm{X}_{3}\right)$, assurance $\left(\mathrm{X}_{4}\right)$, empaty $\left(\mathrm{X}_{5}\right)$ mempunyai pengaruh yang sangat penting terhadap minat konsumen dalam mengkonsumsi jasa servicehandphone.

\section{KESIMPULAN}

1. Secara simultan (uji F) Faktor-faktor yang mempengaruhi minat konsumen terhadap jasa servicehanphone pada Been ponsel Pekanbaru adalah reliability, tangible, responsiveness, assurance, empaty. Semua variable sangat berpengaruh terhadap minat konsumen terhadapjasaservicehandphonne pada $\mathrm{My}$ ponsel.

2. Dari hasil keseluruhan responden terhadap minat konsumen terhadap jasa servicehanphonne pada My ponsel disimpulkan bahwa Ho ditolak dan $\mathrm{Ha}$ diterima jadi semua variable sangat mempengaruhi minat konsumen terhadap jasa servicehandphonne.

3. Faktor yang paling dominan pengaruhnya adalah reliability, pengaruh Variablereliability $\left(\mathrm{X}_{1}\right)$ terhadap variable minat konsumen ( $\mathrm{Y}$ ) menunjukan nilai thitung sebesar 3,544 atau lebih besar dari 
pada t- table ( 1,980$)$. Uji t juga mengatakan bahwa t- hitung variabel reliability, tangible, responsiveness, assurance, empaty lebih besar dari t- tabel berarti Ho ditolak dan Ha diterima.

4. Variablereliability, tangible, responsiveness, assurance, empaty memberikan dampak positif bagi minat konsumen terhadap jasa servicehandphone pada My ponsel.

\subsection{Saran}

Adapun saran - saran yang penulis berikan kepada pada My ponsel berdasarkan penelitian :

1. My ponsel diharapkan untuk meningkatkan minat konsumen tehadapvariable-variable penelitian terutama empaty karena dengan hal tersebut diharapkan para konsumen dapat merasakan kepuasan dalam mengkonsumsi jasa servicehanphone tersebut.

2. My ponsel diharapkan selalu melakukan riset konsumen, baik itu mengenai sikap konsumen, prilaku konsumen dan kepuasan konsumen. Karena data dan informasi yang diperoleh dari riset tersebut dapat membantu dalam melakukan efisiensi dan perbaikan dalam layanan jasa servicehandphone.

Penulis menyarankan mempercepat mereparasi setiap unit hanphone yang rusak menurut peninjauan penulis rata-rata memperbaiki membutuhkan waktu lumayan apalagi kerusakan agak parah maka dibutuhkan berhari-hari untuk pengerjaan.

\section{DAFTAR PUSTAKA}

Alex S. Nitisemito. Marketing. Cetakan ke empat.ghalia Indonesia .Jakarta, 2000

Alma Buchari. 2000, Manajemen Pemasaran dan Pemasaran Jasa, ALFABETA,Bandung.
Amstrong Gary, 2001, Prinsip-Prinsip Pemasaran, Penerbit Erlangga Jakarta

Azwar, Salfuddin, MA, 2005, Sikap manusia Teori dan Pengukurannya, Edisi kedua,Cetakan II. Pustaka Pelajar, Jakarta

Bugin, B. 2005, Metode penelitian Kuantitatif, Pernada Media, Jakarta.

Engel, James F.,RogerD.Blackwell dan Paul W.Miniard 2004, Prilaku Konsumer,Terjemahaan F.X Budianto, Jilid I, Edisi ke-4, Binarupa Aksara, Jakarta.

Fandy Tjiptono. 2002, Manajemen Jasa, andi offset. edisi kedua, cetakan ketiga, Yogyakarta.

Gasperaz, W. 2002, Manajemen Kualitas dalam industri Jasa, cetakan kedua, PT Gramedia Pustaka Utama, Jakarta.

Iqbal, 2000, Pokok-Pokok Statistik,Jilid Dua, Erlangga, Jakarta

J. Supranto. 2002, Pengukuran Tingkat Kepuasan Pelangan, Rineka Cipta, Jakarta.

J.PaulPeter,dan Jerry C.Olson, 2003, ConvatuerBehavior (Prilaku Konsumen dan Strategi Pemasaran), alih Bahasa, DamosSihombing,Edisi ke-4, Erlangga,Jakarta.

James L.Gibson, Jhon, M, Ivan Cevich dan Jaines F. Donnely, Jr, 2003, Organisasi dan Manajemen, (Prilaku, Struktur dan Proses), Edisi ke4, Cetakan kedelapan, Erlangga, Jakarta.

Kotler, Philip, 2004, Manajemen Pemasaran, Edisi Bahasa Indonesia Jilid 2 Alih Bahasa Hendra Teguh, Ronny Antonius Rusli, Prenhallindo, Jakarta. 